JELTL (Journal of English Language Teaching and Linguistics) e-ISSN: 2502-6062, p-ISSN: 2503-1848

2020, Vol. 5(3)

www.jeltl.org

\title{
Student-Teachers' Engagement in Mediated Writing Feedback: Narrative Inquiry
}

\author{
Muhammad Reza Pahlevi \\ Universitas Singaperbangsa Karawang \\ mreza.pahlevi@fkip.unsika.ac.id
}

\begin{abstract}
Advance of technology brings about different ways in language learning and teaching. Indeed, mediated writing feedback has been adopted and demanded in language assessment. However, little is known on how students' engagement in mediated writing feedback. This present study explores students' engagement in mediated writing feedback. Narrative inquiry design was used to reveal students' experience and reflection of mediated writing feedback. Three student-teachers involved in this study. They assigned as they meet requirement in this study. They were in thesis writing. Semi-structured interview used to reveal students' learning experience in receiving mediated writing feedback. Students' writing work used in this study as well. The obtained data were analyzed by thematic analysis. They also interpreted by theories lenses. The findings illustrated that mediated writing feedback stimulates students learn to write actively (behavior engagement), assists students learn to write (cognitive engagement), and have a balance emotion (emotional engagement.)

Keywords: mediated writing feedback, students' engagement, student-teachers, narrative inquiry
\end{abstract}

\section{INTRODUCTION}

Writing feedback becomes crucial in initiating students learn to write. It is closely on how students are engaged and what factors that influenced students to engage in learning to write. Many factors that impact students' engagement like social support (teachers, peers, and family members) and sense of community as direct and indirect factors. However, only teachers role that significantly influenced students' engagement in learning (Vayre \& Vonthron, 2017). Therefore, teachers take essential role in collaborating with the students in learning to write. Empirical evidence reported by Guasch et al., (2013) point out that best 


\section{Muhammad Reza Pahlevi}

collaborative writing feedback refers to epistemic and suggested feedback. Both of them stimulated and equipped students in learning to write. Latifi et al., (2019) compared that scripted online feedback equipped students learn to write collaboratively then unscripted and guided online peer-feedback. However, it has been explored recently (Stödberg, 2011). It derives from internet access that enables students to learn more about subject (Tseng \& Tsai, 2007). It stimulates students actively interact whether receiving or giving writing feedback (Yang, 2010). Although, online feedback beneficial for students in learning to write, there is empirical evidence reported by Morgan \& Toledro (2006) some students retains assigning handwritten feedback than typewritten. However, little is known on how students engage in mediated writing feedback. Indeed, the success of learning is reflected by their motivation to engage in learning activity (Big \& Tang, 2007).

In language classroom, feedback has been documented properly by researchers. It becomes a crucial and essential phase in learning to write (Guardado \& Shi, 2007). This phase potentially not only engage students collaboratively but also encourage them learn to practice English meaningfully (Liu \& Hansen, 2002). They are facilitated through synchronous and asynchronous access. Therefore, they easily learn subject in flexibility. They are also trained learn to practice writing each other's. Related to online feedback has fewer destruction which support students to participate (Guarardo \& Shi). It deals also with obstacles like signal and technology advance.

Peer feedback has been widely explored by many researchers. They tend to examine peer feedback's interaction (DiGiovanni \& Nagaswami, 2001; Honeycutt, 2001) and conduct research about the effect of peer comments on revision and quality of the final paper (Braine, 2001; Hewett, 2000; Liu \& Sadler, 2003; Matsumura \& Hann, 2004; Sullivan \& Pratt, 1996; Tuzi, 2004). Their findings showed that e-feedback has beneficial in its interactive textual exchange and greater students' participation tough its impact on revision seems to vary in individual studies. Based on mentioned previous study, it is clearly that students' engagement in mediated feedback is under-explored, therefore this present study concerns on how students engage in mediated writing feedback.

\section{LITERATURE REVIEW}

\subsection{Students' engagement in mediated writing feedback}

Students which engage in online peer feedback stay comfort and remain on their task (DiGiovanni \& Nagaswami 2001). They were delighted to participate in online platform. Sullivan \& Pratt (1996) report that writing class that utilized online platform gained 100\% participation compared to face-to face was half interaction. Student engagement consists of behavioral, cognitive and emotional scopes. Behavioral engagement is illustrated by observable behavioral characteristics, like level of investment that is dedicated to learning or the level of learning gain; they defined emotional engagement as learners' emotions about learning, such as interest, boredom, and happiness (Marks \& Newmann). Finn in (Lee et al., 2019) explained that student engagement is determined by behavioral factors (participation) and emotional factors (identification) in his presentation of the participation-identification model. The behavior factor is represented from students' attitude toward learning, such as questioning or submitting assignments, and the emotional factor is presented from the 
students' feelings toward learning, such as their involvement to the learning. Moreover, there are other types of engagement like cognitive, academic, and performance engagement. Cognitive engagement is closely related to learners' asset of thought, mental effort, or learning achievement strategies. Academic engagement is represented by learning activities, such as time that is devoted in learning tasks, task submission, learning outcomes, etc. Performance engagement is connected to academic engagement. It signifies the level of learning performance, which is connected to autonomy in learning, grades in learning, and have a test scores, and so on (Lee et al., 2019).

\subsection{Washback effect on mediated writing feedback}

One of these effective ways to improve students' learning is to apply a proper form of assessment. Principles of language assessment, according to Brown (2004, pp. 15-30) covers practicality, reliability, validity, authenticity and backwash. Practicality means that assessment procedure needs to be reasonable, time-efficient, specific and relatively easy to understand. Reliability refers to test consistency and dependability. Validity implies that assessment results are representatively appropriate, meaningful and useful in terms of the purpose of the assessment. Authenticity is indicated by the following: (1) the language in the test is as natural as possible; (2) its items are contextualized rather than isolated; (3) topics are meaningful (relevant, interesting) for the learners; and (4) tasks represent, or closely approximate, real-world tasks. Backwash is the effect of testing on teaching and learning. Backwash also implies that students have ready access to the teacher/lecturer to discuss the feedback and evaluation he/she has given.

The term backwash implies the (either negative or positive) effects of assessment on teaching and learning. Some writers believe that it is possible to bring about changes in language teaching by changing tests (Cumming \& Berwick, 1996). If an assessment has positive backwash effects, it will exert a good influence on the learning and teaching that takes place before the assessment. However, language tests are frequently criticized for having negative impact on teaching then so-called "negative backwash".

Journals assessment is one of type assessment account of one's thoughts, feelings, reactions, assessments, ideas, or progress towards goals, usually written with little attention to structure, form, or correctness (2004, p. 260). It means learner can communicate their thought freely. Journals obviously serve important pedagogical purposes: practice in the mechanics of writing, using writing as a thinking process, individualization, and communications with the teacher. In addition, the most classroom-oriented journals are dialogue journals (2004, p. 260). The steps for applying journals are (1) Sensitively introduce students to the concept of journal writing, (2) state the objective(s) of the journal: Language-learning logs, Grammar journals, Responses to readings, strategies-based learning logs, Self-assessment reflections, etc., (3) Give guidelines on what kinds of topics to include, (4) Carefully specify the criteria for assessing or grading journals. Provide optimal feedback in your responses: cheerleading feedback, instructional feedback, or reality-check feedback, (5) Provide optimal feedback in your responses, (6) Designate appropriate time frames and schedules for review, (7) Provide formative, washback-giving final comments.

In terms of backwash relates to assessment is important. One of the kinds of journal is reflective journal. A reflective journal is a way of thinking in a critical and analytical way 


\section{Muhammad Reza Pahlevi}

about our work in progress. It shows how different aspects of our work interconnect. The journal can record: where our inspiration comes from, how we make use of our ideas to develop our work, and our awareness of the cultural context (setting) in which we work. This context includes: other artists' work and their ideas; the ideas of critics and theorists; social, political, aesthetic and ideological contexts (Oxford Brookes University, 2016).

\section{RESEARCH METHODS}

\subsection{Research Design}

This present study aimed at finding student teachers' engagement in mediated writing feedback. The mediated writing feedback provides private comment for refining students' writing. The feedback is in asynchronous through MS words comment column. To reveal students' engagement on mediated writing feedback, narrative inquiry design was used in this study. Students teachers' engagement were represented by their experience in mediated writing feedback. A narrative inquiry design was used to explore someone' experiences (Clandinin \& Connely, 2000; Clandinin \& Rosiek, 2007). This design assisted in gaining students teachers' engagement experience in mediated writing feedback. Students teachers' experiences by their engagement in mediated writing feedback were studied deeply and thoroughly. Thus the findings were analyzed and interpreted thematic analysis and theories lenses.

\subsection{Participants}

This research was initiated by consedering students teachers who wrote their thesis in mediated writing feedback. They were informed to be participated voluntary. There were ten students who wrote thesis but only three students who agreed to be interviewed. The consideration of assigning students wo involved in this study referred to their experiences on writing thesis in mediated writing feedback. To ensure their participation, students teachers' demography information was presented. Table 1 represents student teachers' demography information.

\section{Tabel 1. Student teacher demography information}

\begin{tabular}{|l|l|l|l|l|l|l|}
\hline $\begin{array}{l}\text { Participants } \\
\text { (Pseudonym) }\end{array}$ & Gender & Age & $\begin{array}{l}\text { Linguistics } \\
\text { Background }\end{array}$ & $\begin{array}{l}\text { Education } \\
\text { Background }\end{array}$ & $\begin{array}{l}\text { Length of } \\
\text { English } \\
\text { Learning } \\
\text { Experience }\end{array}$ & $\begin{array}{l}\text { Social- } \\
\text { economy } \\
\text { background }\end{array}$ \\
\hline Nanda & Female & 19 & $\begin{array}{l}\text { Sundanese } \\
\text { Indonesian } \\
\text { Arabic }\end{array}$ & $\begin{array}{l}\text { Undergraduate } \\
\text { studies }\end{array}$ & 10 years & Medium \\
\hline Ni Made & Female & 19 & $\begin{array}{l}\text { Javanese } \\
\text { Indonesian }\end{array}$ & $\begin{array}{l}\text { Undergraduate } \\
\text { studies }\end{array}$ & 10 years & Medium \\
\hline Rangga & Male & 19 & $\begin{array}{l}\text { Sundanese } \\
\text { Indonesian }\end{array}$ & $\begin{array}{l}\text { Undergraduate } \\
\text { studies }\end{array}$ & 10 years & Medium \\
\hline
\end{tabular}

Adopted from Yanto \& Pravitasari ( 2020). 
This present study spent three months. The participants were encouraged to fully participate in the interviewed section. The participants were agreed to be volunteers. They were given inform consent. They were expressed their experiences in online feedback.

\subsection{Instruments}

To obtain data, this study used open-ended interview and sample feedback. The interview used in Bahasa to make it easier and ensure student teachers' experiences of engagement in online writing feedback. The interview concerns on revealing student teachers' engagement experiences in online writing feedback. The interview spent 40-45 minutes and it conducted with relaxed and warm interview. In each interview section, the participants shared their experiences of engagement in online writing feedback. In order to strengthen the interview data, sample feedback was used to elicit student teachers' engagement.

\subsection{Data Analysis}

Interview data were selected and transcribed in depth, close selective, and analytical listening to get a comprehensive message or meaning represented in the interview (Widodo 2014). The selected and transcribed data were made findings thematically. It also analyzed through thematic analysis (Braun \& Clark, 2006). Thematic analysis on this study focused on content experiences not on linguistics features of each utterance. Each student teachers' experiences/stories of engagement in writing mediated feedback. The data were interpreted through thematic lenses.

\section{FINDINGS}

There are three findings of student teachers' engagement in mediated writing feedback. The mediated writing feedback stimulated the student teachers learn to write actively (behavior engagement), students teachers equipped learn to write (cognitive engagement), and had a balance emotion (emotional engagement). The detailed findings are presented here.

\subsection{The mediated writing feedback stimulated the student-teachers learn to write actively (behavior engagement)}

Student teachers were inspired and equipped learn to write actively. They were involved in relaxed discussion on accepting the feedback. It can be traced from the interview which explored students' engagement in online writing feedbacks.

Researcher : How was your learning experience on online writing?

Participant 1 : I assisted in revising my paper by seeing highlighting revised points.

Participant2 : It made me easier in having collaboration of writing.

Participant3 : It encouraged me to revise and rewrite.

(Interview transcription data 1)

The interview transcription illustrated that the student teachers agreed and admitted that they were equipped and encouraged learn to write in writing mediated feedback. It enabled them learn to write collaboratively. They expressed that the efficiency and easiness 


\section{Muhammad Reza Pahlevi}

on having feedback helped them in learning to write. This obtained data was strengthen by virtual documentation of student teachers' writing thesis revision.

\section{A. Background of Research}

Assessment has become crucial in language teaching. It becomes evaluation

of students' progress. Common assessment used in Indonesian classroom is formative and summative assessment. (here you can describe on how formative and summative are applied in the classroom-In addition, formative and summative assessment has been widely explored by researchers. It is found Widiastuti \& Saukah (2017) find out formative assessment is really necessary for teachers to provide student's feedback to improve their learning achievement and modify their learning styles. Furthermore, based on Ridhwan, M. (2017) s Summative assessment refers to the fact that, when teachers summarize students' learning at the end of the teaching cycle, they may use or not have to provide feedback information (formative assessment) to improve teaching and learning. However, digital learning cannot be avoided in education especially assessment. (here you can add evidence importance of digital learning). Therefore, it is essential to adopt digital in assessment. Sort of digital media in assessment is Edmodo. a few research concerns

\subsection{Sample feedback}

Based on presented the sample feedback, the student teachers were facilitated learn to write collaboratively with teachers. Some recommended points assisted them on refining their paper well. Suggested points developed student teachers' ideas on writing as well. Thus, they were able to write properly.

\section{A. Background of Research}

The EFL teachers in Indonesia understand that classroom assessment method should be regarded as a procedure rather than as a tool. The object of the assessment is not just to achieve student scores and to decide whether or not they fulfill the criteria, but also to know more about the development of students in learning and to mediate them in order to be effective in learning. Assessment has become crucial in language teaching. It becomes evaluation of students' progress. Common assessment used in Indonesian classroom is formative and summative assessment. According to Brown, H. (2010), formative assessment is evaluating students in the process of "training" their abilities and knowledge with the goal of encouraging them to begin the progress of learning. Formative assessment is when you give comments or suggestions to students, or pay attention to mistakes, that feedback is offered to improve quality of language ability. While, summative assessment is meant to evaluate, or summarize, what the student has learned and typically comes at the end of a course or unit of instruction (Brown, H, 2010). Course final exams and general proficiency assessments are forms of summative assessment.

In addition, formative and summative assessment has been widely explored by researchers. It is found Widiastuti \& Saukah (2017) find out formative assessment is really necessary for teachers to provide student's feedback to

\subsection{Sample feedback}


The revised paper showed that the student teachers were inspired and equipped in learning to write. The mediated writing feedback helped them to write well. They learned on how to strengthen their writing by discussing writing context and evidence. Therefore, they were capable to write appropriately. The student-teacher were engaged behaviorally as they were facilitated having mediated writing feedback. It helped them to have positive attitude to write. It also leads them to be self-regulated learning since they had awareness of refining their own writing. Thus, the student-teachers keep on writing their paper simultaneously. It can be traced from interview transcription below.

Researcher: How was your learning experiences on receiving mediated writing feedback?

Participant1: My experience of doing mediated writing feedback is a completely different experience from usual. Because in terms of communication, it seems like we have limitations and are also not flexible when providing guidance. Not to mention that the quota that must be demanded is always available to track progress, get the latest news on feedback that may have been sent as well as to send revisions back.

Participant2: Experience was very interesting, because the initial guidance was face-to-face then moved to using mediated writing feedback. It is just that the feel is very different between face to face guidance and mediated writing feedback.

Participant3: I learned how to receive feedback in mediated writing feedback. It coped me in refining my proposal writing.

Based on mentioned the interview transcription, it represented that students' experience on accepting mediated writing feedback perceived differently from the students. There are opportunities and challenges on mediated writing feedback.

\subsection{Mediated writing feedback assists student teachers in writing (cognitive engagement)}

The students trained to do the task. They were involved in collaborative writing trough mediated writing feedback. It coped them to generate ideas of writing and transform them in to writing. They also assisted to write theses as it provided synchronous feedback. It can be seen from interview transcriptions result.

Researcher: In what ways does online feedback assist you in learning to write?

Participant 1: Highlighted points generated ideas of writing.

Participant2: Synchronous feedback helped me in developing my writing.

Participant3: It showed me on how to write well.

Based on interview transcription result, it illustrated that students were actively engaged to write. It helped them to accomplish the writing task. The mediated writing feedback guided them to write well. Therefore, they could easily do the task. It helped the students to write. 


\subsection{Students had balance emotion on online feedback.}

The students perceived online feedback distinctively. The mediated writing feedback brings about easiness and difficulties. It is closely related to efficiency and access. The students expressed this condition in the interview transcription.

Researcher : What opportunity and challenges of online feedback?

Participant 1 : I could check my writing revision directly but I have connection probleminternet access.

Participant2 : I was able to develop my writing since it guided by lecturer. Although sometimes I am still nervous, I could adopt it.

Participant3 : Honestly, I admitted that online feedback brings positive and negative. Faceto face meeting has strong suggestion than online platform.

Referred to the interview transcription, it is clearly demonstrated that mediated writing feedback responded differently. It means that mediated feedback has strengths and weaknesses in learning to write. However, they were mediated learn to write thesis properly although they had a balance emotion-postive and negative perceptions.

\section{DISCUSSION}

\subsection{The mediated writing feedback stimulated the student-teachers learn to write} actively (behavior engagement)

The student teachers were encouraged to be actively participated in learning to write in mediated feedback platform. It is in line with Liu \& Hansen (2002) claim that feedback in online platform build not only collaboration but also provide to practice English meaningfully. It also lead students to actively engage in writing process. Thus, they had access to revise and involved (Honeycutt, 2001). The involvement brought about solid participation, interaction and engagement. Thus it created them to be reflective practice. It is same with Guarardo \& Shi (2007) point out online feedback has less threatening that encourage student teachers' participation. Mediated writing feedback provides interactive feedback that scafold students' interaction. Thus, student teachers were engaged behaviorally. It is same with Golladay Prybutok and Huff (2000) successful online learners determine to what extent their participation in peers, motivation to learn, provide proper amount of time to learn, and utilize technology in their learning. It becomes essential stages of facilitating students to actively involved in mediated writing feedback.

\subsection{Mediated writing feedback assists student teachers in writing (cognitive engagement)}

Student teachers were assisted on learning to write and revise (Berg, 1999; Min, 2005, 2006). They were facilitated learn to write well. They also had fully interaction in learning to write (Sullivan \& Pratt, 1996). They remained in writing theses as they mediated to have discussion in online platform (DiGiovanni \& Nagaswami, 2001). They were engaged cognitively. Mediated writing feedback had positive washback that inspired and lead 
students learn to write easily. The writing process consists of inventing ideas through brainstorming, drafting, writing, editing, revising, and publishing. It also gave students guidance and meaningful revision of their paper. In addition, mediated writing feedback gave impacts for students to write well. It is closely related to washback effect (Cumming \& Berwick, 1996).

\subsection{The student teacher had a balance emotion in mediated writing feedback.}

As online feedback not only brings about easiness but also difficulty in having access. They were engaged emotionally-positive and negative perceptions. Positive perceptions stem from easiness of accepting feedback, negotiated meaningful revision and collaborated writing (Lee, Song, \& Hong, 2019). In other hand negative perceptions come from difficulties transmit teacher's guidance to revise paper. Although it is mediated clearly, sometime it still have obstacles on it. Having balance emotion is normal situation as mediated writing feedback also depends on students who accept its feedback.

\section{CONCLUSION}

Mediated writing feedback potentially engages student teachers in learning to write. They were actively engaged in learning to write thesis in terms of behavior engagement, cognitive engagement and emotional engagement. Mediated writing feedback stimulated and equipped students learn to write collaboratively. It also helped the student teachers to generate writing ideas. Thus, mediated feedback prepared students in learning to write in mediated platform-assisted. It creates students not only learning to write but learning to collaborate.

Mediated writing feedback serves students to explore their writing through accepting feedback. It helps them to train writing through provided mediated feedback. The students are facilitated on following writing stages by mediated writing feedback. It also builds students' awareness to be self-regulated learner which led their writing through mediated writing feedback.

Mediated writing feedback perceived differently-positive and negative responses. It deals with easiness and difficulties on accepting and respond mediated writing feedback. It also engages them in balance emotion-happiness and bored. In sum up mediated writing feedback engages students whether in behavior, cognitive, and emotion. It also has positive washback effect that builds students to have awareness of writing paper by considering accepted feedback.

\section{REFERENCES}

Biggs, J. \& Tang, C. (2007), Teaching for Quality Learning at University What the Student Does, 3rd edition, McGraw-Hill Education, Maidenhead, Blacklick.

Braine, George. (2004). Teaching second and foreign language writing on local area networks (LANs). In Sandra Fotos \& Charles M. Browne (Eds.), New perspectives on CALL for second language classrooms (pp. 93-108). NJ: Lawrence Erlbaum. 


\section{Muhammad Reza Pahlevi}

Braun, Virginia \& Clarke, Victoria. (2006). Using thematic analysis in psychology. Qualitative Research in Psychology. 3. 77-101. 10.1191/1478088706qp063oa.

Brown, H. D. (2004). Language assessment: Principles and classroom practices. San Francisco California: Pearson Education.

Clandinin, D. J., \& Connelly, F. M. (2000). Narrative inquiry: Experience and story in qualitative research. San Francisco, CA: Jossey-Bass.

Clandinin, D. J., \& Rosiek, J. (2007). Mapping the landscape of narrative inquiry:Borderlands spaces and tensions. In D. J. Clandinin (Ed.), Handbook of narrative inquiry: Mapping a methodology (pp. 35-76). Thousand Oaks, CA: Sage.

Cumming, A., \& Berwick, R. (1996). Validation in Language Testing (Modern Languages in Practice: 2). Adelaide: Multilingual Matters, Ltd.

DiGiovanni, Elaine, \&Nagaswami, Girija. (2001). Online peer review: An alternative to face-to-face? ELTJournal, 53, 263-272.

Golladay, R.M.; Prybutok, V.R.; Huff, R.A. Critical success factors for the online learner. J. Comp. Inform. Syst. 2000, 40, 69-71.

Guardado, M., \& Shi, L. (2007). ESL students' experiences of online peer feedback. Computers and Composition, 24(4), 443-461. https://doi.org/10.1016/j.compcom.2007.03.002

Guasch, T., Espasa, A., Alvarez, I. M., \& Kirschner, P. A. (2013). Effects of feedback on collaborative writing in an online learning environment. Distance Education, 34(3), 324-338. https://doi.org/10.1080/01587919.2013.835772

Hickson, Hellen. 2016. Critical reflection: reflecting on learning to be reflective. Retrieved from http://www.researchgate.net.

Latifi, S., Noroozi, O., Hatami, J., \& Biemans, H. J. A. (2019). How does online peer feedback improve argumentative essay writing and learning? Innovations in Education and Teaching International, $00(00), \quad 1-12$. https://doi.org/10.1080/14703297.2019.1687005

Lee, J., Song, H. D., \& Hong, A. J. (2019). Exploring factors, and indicators for measuring students' sustainable engagement in e-learning. Sustainability (Switzerland), 11(4). https://doi.org/10.3390/su11040985

Mayer, Richard E. (2008). Learning and instruction. United State of America: Pearson Prentice Hall.

Morgan, V. L., \& Toledo, C. A. (2006). Online Feedback and Student Perceptions. Journal of Interactive Online Learning Www.Ncolr.Org/Jiol, 5(3). www.ncolr.org/jiol

Oxford Brookes University. (2016). Reflective journal. Retrieved from http://www.brookes.ac.uk.

Kopriva, Rebecca. (2008). Improving testing for English language learners. New York: Routledge.

Vayre, E., \& Von-thron, A. M. (2017). Psychological Engagement of Students in Distance and Online Learning: Effects of Self-Efficacy and Psychosocial Processes. Journal of Educational Computing Research, 55(2), 197-218. https://doi.org/10.1177/0735633116656849 
Stödberg, U. (2011), “A research review of e-assessment”, Assessment \& Evaluation in Higher Education, Vol. 37, No. 5, pp. 591-604.

Sullivan, Nancy, \&Pratt, Ellen. (1996). Acomparative study oftwoESL writing environments:Acomputer-assisted classroom and a traditional oral classroom. System, 24, 491-501.

Tuckman, B.W. (1975). Measuring educational outcomes (fundamentals of testing). San Fracisco:Harcourt Brace Jovanovich, Inc.

Tseng, S. C., \& Tsai, C. C. (2007). On-line peer assessment and the role of the peer feedback: A study of high school computer course. Computers \& Education, 49(4), 1161-1174.

Yang, Y.-F. (2010). A reciprocal peer review system to support college students' writing. British Journal of Educational Technology. doi:10.1111/j.1467-8535.2010.01059.x.

Guardado, M., \& Shi, L. (2007). ESL students' experiences of online peer feedback. Computers and Composition, 24(4), 443-461. https://doi.org/10.1016/j.compcom.2007.03.002

Guasch, T., Espasa, A., Alvarez, I. M., \& Kirschner, P. A. (2013). Effects of feedback on collaborative writing in an online learning environment. Distance Education, 34(3), 324-338. https://doi.org/10.1080/01587919.2013.835772

Latifi, S., Noroozi, O., Hatami, J., \& Biemans, H. J. A. (2019). How does online peer feedback improve argumentative essay writing and learning? Innovations in Education and Teaching International, 00(00), 1-12. https://doi.org/10.1080/14703297.2019.1687005

Lee, J., Song, H. D., \& Hong, A. J. (2019). Exploring factors, and indicators for measuring students' sustainable engagement in e-learning. Sustainability (Switzerland), 11(4). https://doi.org/10.3390/su11040985

Morgan, V. L., \& Toledo, C. A. (2006). Online Feedback and Student Perceptions. Journal of Interactive Online Learning Www.Ncolr.Org/Jiol, 5(3). www.ncolr.org/jiol

Ramdani, J.,\& Widodo, H. (2019). Student teachers' engagement in facebook-assisted peer assessment in an initial teacher education context: speaking 2.0. Journal of Education for Teaching. http://doi.org/10.1080/09589236.2019.1599503.

Vayre, E., \& Vonthron, A. M. (2017). Psychological Engagement of Students in Distance and Online Learning: Effects of Self-Efficacy and Psychosocial Processes. Journal of Educational Computing Research, 55(2), 197-218. https://doi.org/10.1177/0735633116656849

Yanto, E. S., \& Pravitasari, H. (2020). Experiences In The Indonesian ESP Classroom Context A Narrative Inquiry Of Student Teachers Multimodal Practice Experiences In The Indonesian ESP Classroom Context. 12-20. 